\title{
Isolation and partial characterization of Asian sea bass (Lates calcarifer) Vitellogenin
}

\author{
N. M. R. Fazielawanie • S. S. Siraj • S. A. Harmin • \\ M. Y. Ina-Salwany
}

Received: 24 February 2012/Accepted: 4 July 2012/Published online: 10 August 2012

(C) The Author(s) 2012. This article is published with open access at Springerlink.com

\begin{abstract}
A study was conducted to isolate, partial characterize Asian sea bass (Lates calcarifer) vitellogenin (vtg). Two-year-old juvenile $L$. calcarifer $(n=10)$ were given three intraperitoneal injections of 17- $\beta$ estradiol $\left(E_{2}\right)$ at a dose of $2 \mathrm{mg} / \mathrm{kg}$ body weight to induce vitellogenesis. Blood was collected 3 days after the last injection, and plasma was purified through gel filtration chromatography. A broad single symmetrical peak consisting of vtg molecule was produced. Protein concentration was $0.059 \mathrm{mg} / \mathrm{ml}$ as determined by Bradfrod assay using bovine serum albumin as a standard. The protein appeared as one circulating form in Native PAGE considering the dimeric form of putative vtg with molecular weight of $545 \mathrm{kDa}$. In SDS-PAGE under reducing conditions, two major bands appeared at 232.86 and $118.80 \mathrm{kDa}$ and minor bands at 100.60, 85.80 and $39.92 \mathrm{kDa}$, respectively. The purified vtg was used to generate a polyclonal antibody, and the specificity of antibody
\end{abstract}

N. M. R. Fazielawanie · S. S. Siraj ( $₫)$.

M. Y. Ina-Salwany

Department of Aquaculture, Faculty of Agriculture, University Putra Malaysia (UPM), 43400 Serdang,

Selangor, Malaysia

e-mail: shapor@putra.upm.edu.my

\section{S. A. Harmin}

Centre for Land and Aquatic Technology, Faculty of Science and Biotechnology, University Industry Selangor (UNISEL), 45600 Batang Berjuntai,

Selangor, Malaysia was assessed by Western blot analysis. Two major bands were immunoreacted, but no cross-reactivity was observed with plasma from non-induced males. The protein was characterized as phosphoglycolipoprotein as it positively stained for the presence of lipid, phosphorus and carbohydrate using Sudan Black B, methyl green and periodic acid/Schiff reagent solution, respectively. The amino acid composition was analyzed by high sensitivity amino acid analysis that showed high percentage of non-polar amino acids $(\sim 48 \%)$. The results suggest the potential utilization of vtg as a basis tool to further study about reproductive physiology of this important economical species.

Keywords Chromatography - Lates calcarifer . Phosphoglycolipoprotein · Vitellogenin · Western blot · Amino acid analysis

\section{Introduction}

Lates calcarifer, known as barramundi, Asian sea bass or locally called siakap, is native to coastal Australia, Southeast and Eastern Asia, and India (Luna 2008). This species are farmed in cages, as well as in fresh water and salt water ponds (Webster and Lim 2002). In recent years, sea bass has gained growing importance in aquaculture both as recreational and commercial fish, with a high and fairly stable price (Luna 2008). Sea bass production and consumption in Malaysia has increased dramatically over the years from 49, 586.19 
(DOF 2005) to 194, 623.11 tonnes (DOF 2009). In spite of its economic importance, knowledge about its reproductive physiology is limited. In recent years, the reproductive biology of many fish species has been studied by analyzing the vitellogenin (vtg) levels in the blood plasma (Susca et al. 2001).

Vitellogenin is an egg yolk precursor protein that is synthesized in the liver under estrogen control and secreted into the bloodstream (Celius and Walther 1998; Prakash et al. 2007). This large protein has high molecular weight ranging from 250 to $600 \mathrm{kDa}$ depending on fish species (Utarabhand and Bunlipatanon 1996). In teleost oviparous fish, vtg is served as a nutritional source for growing oocyte and developing embryo in matured female through a process called vitellogenesis (Romano et al. 2004). Following oocyte growth, vtg will enzymatically cleave into smaller yolk proteins namely lapidated lipovitellin, phosphorylated phosvitin and $\beta$-components (Zhang et al. 2011). Mananos et al. (1994) noted that the main components that contribute to the circulation of vtg molecule are lipids, carbohydrates, phosphorus and various ions such as calcium and iron. The vtg was present in adult vitellogenic females but absent in male as well as in immature females (Nath 1999; Fenske et al. 2001). In vertebrate, vtg gene is expressed in male and immatured female, but insufficient circulating estrogen is incapable to enhance the production of this protein (Palumbo et al. 2007). However, these organisms will synthesize the vtg if they are administered with synthetic estrogens, mainly 17- $\beta$ estradiol (Leonardi et al. 2010; Boucard et al. 2008). Estradiol was reported to successfully induce the synthesis of vtg in many fish species (Utarabhand and Bunlipatanon 1996; Mendoza et al. 2011). The levels of vtg in fish indicate the maturing stage in female individual under natural condition (Matsubara et al. 1994). Knowledge of reproductive physiology including vitellogenesis is very important in managing fish broodstock for reproduction in most farmed animals including fish.

Previous studies reported that vtg has been isolated and purified in many fish species including Senegalese sole (Solea senegalensis) (Guzman et al. 2008), grouper (Ephinephelus malabaricus) (Utarabhand and Bunlipatanon 1996), California halibut (Paralichthys californicus) (Palumbo et al. 2007), Chilean flounder (Paralichthys adpersus) (Leonardi et al. 2010) and sea bass (Dicentrarchus labrax L.)
(Mananos et al. 1994) by using double chromatography, ion exchange followed by gel filtration chromatography. However, Watts et al. (2003) and Mendoza et al. (2011) have proven that gel filtration alone using Sepachryl 16/60 HR-300 column was able to completely isolate vtg in three teleost species.

Vitellogenin has never been purified and characterized in L. calcarifer, and knowledge about its reproduction and vitellogenesis is needed. A better understanding of vitellogenesis is very important for farm management as well as to determine the maturity status of this economically important species (Utarabhand and Bunlipatanon 1996). Thus, the aim of this study was to induce, purify and characterize the $v$ tg from $\mathrm{E}_{2}$-treated juvenile $L$. calcarifer.

\section{Materials and methods}

\section{Experimental animals}

Sampling was done at Center of Marine Science, Universiti Putra Malaysia, Port Dickson, Malaysia. Two-year-old juvenile Asian sea bass (L. calcarifer) $(n=10)$, ranging in weight from $1.5 \pm 0.5 \mathrm{~kg}$, were obtained from commercial supplier, while matured males and vitellogenic females, weighing around 4.0 $6.3 \mathrm{~kg}$, were obtained from Fisheries Research Institute, Tanjung Demong, Terengganu, Malaysia. They were maintained for 2 weeks in 10-tonne tank with filtered, flow-through seawater at salinity of $29 \pm 1 \mathrm{ppm}$, a temperature of $21 \pm 2{ }^{\circ} \mathrm{C}, \mathrm{pH}$ of 6.0 6.5 and supplied with dissolved oxygen $(5.4 \mathrm{mg} / \mathrm{ml})$. Fishes were tagged using microchips for further identification and fed daily at satiation with chopped fresh fish.

\section{Induction of vtg}

Each juvenile fish was injected with $17-\beta$ estradiol, $E_{2}$ (Nacalai Tesque, Japan) to induce the vitellogenesis. They received a total of three intraperitoneal injections (i.p.) (dose of $2 \mathrm{mg} \mathrm{E}_{2} / \mathrm{kg}$ fish body weight), given every 2 days. Estradiol was dissolved in ethanol and $0.9 \% \mathrm{NaCl}$ solution $(1: 9, \mathrm{v} / \mathrm{v})$ as a carrier. Control fishes $(n=6)$ were injected with saline only, and no foods were administered during the experiment. 
Plasma preparation

Three days following the last injection, four millilitres of blood was collected from the caudal vein of each fish using heparinized syringe containing phenylmethylsolfonyl fluoride, PMSF (Roche, Germany) $(100 \mu \mathrm{l}, 1 \mathrm{mM})$. The blood was maintained on ice, allowed to clot at $4^{\circ} \mathrm{C}$ for $1 \mathrm{~h}$ and centrifuged at $8,000 \mathrm{rpm}$ for $10 \mathrm{~min}$ at $5^{\circ} \mathrm{C}$ (Braathen et al. 2009). The supernatant (plasma) was withdrawn and immediately stored in the presence of PMSF to avoid proteolysis of $\mathrm{vtg}$ at a ratio of $2: 1 \mathrm{v} / \mathrm{v}$ (plasma: PMSF) (Watts et al. 2003). It was stored at $-80{ }^{\circ} \mathrm{C}$ prior to vitellogenic purification (Parks et al. 1999). At the same time, blood was collected from control group (vitellogenic females and non-induced males).

\section{Purification of vtg}

Plasma vtg was purified using gel filtration chromatography (Akta Prime) performed at room temperature according to Watts et al. (2003) with modifications. One millilitre of plasma from estradiol treated juvenile L. calcarifer was loaded into prepacked Sepachryl HR300 column (HiPrep 16/60) (GE Healthcare BioScience, Uppsala, Sweden). The samples were eluted with $0.05 \mathrm{M}$ Tris- $\mathrm{HCl} \mathrm{pH} 8.0$ (Nacalai tesque, Japan) at a flow rate of $0.4 \mathrm{ml} / \mathrm{min}$. The elution profile was monitored at $280 \mathrm{~nm}$, and the fractions containing vtg peak were collected at a final volume of $5 \mathrm{ml}$. The purified vtg consisting peak was pooled and directly concentrated using Vivaspin centrifuge tube $(30 \mathrm{kDa}$ Molecular weight cut-off, GE Healthcare Bio-Science, Uppsala, Sweden) at $4{ }^{\circ} \mathrm{C}, 10,000 \mathrm{rpm}$ for $10 \mathrm{~min}$. It was stored at $-20{ }^{\circ} \mathrm{C}$ in aliquots before subjected to Native PAGE and SDS-PAGE analysis. The purified vtg was used as antigen for antibody production against vtg in rabbits. The protein concentration was determined by Bradford assay using bovine serum albumin (BSA) (Sigma Diagnostics, USA) as standard.

\section{Characterization of purified vtg}

\section{Native PAGE}

To determine the purity and molecular weight of circulating form of $L$. calcarifer $\mathrm{vtg}$, purified plasma was subjected to Native gradient PAGE (4-8 \% separating gel solution) (Sun and Zhang 2001) with constant current of $100 \mathrm{~mA}$ for $4 \mathrm{~h}$ on ice in an electrophoretic buffer $(0.025 \mathrm{M}$ Tris and $0.192 \mathrm{M}$ glycine. The molecular weight was determined by comparing with Native markers (Serva, Heidelberg, Germany). Separated protein was identified as phosphoglycolipoprotein (vtg) after staining with Sudan Black B, periodic acid/Schiff reagent solution (PAS) and methyl blue (Nacalai tesque, Japan) to determine the presence of lipid, carbohydrate and phosphorus, respectively.

\section{Sodium dodecyl sulfate polyacrylamide gel electrophoresis (SDS-PAGE)}

To determine the molecular weight of vtg subunits, the purified plasma vtg was electrophoresed (SDSPAGE) under denaturing conditions. It was performed on $7.5 \%$ separating gel and $4 \%$ stacking gel. Prior to application on the gel, the purified vtg were diluted in SDS sample buffer $(125 \mathrm{mM}$ Tris-HCl, $10 \%$ SDS, $20 \%$ v/v glycerol, $5 \%$ v/v $\beta$-mercaptoethanol, $0.02 \%$ bromophenol blue) $(15 \mu \mathrm{g} / \mathrm{ml})$ and boiled for $5 \mathrm{~min}$. Electrophoresis was run on ice in a buffer (50 mM Tris, $192 \mathrm{mM}$ glycine and $0.1 \%$ SDS) at a constant current of $100 \mathrm{~mA}, 50 \mathrm{~V}$ for $5 \mathrm{~h}$ and immediately subjected to Western blot analysis. The results obtained were viewed using gel imager (Alpha Innotech, Cell Bioscience, California). The molecular weights of purified vtg were estimated by comparing with molecular weight protein markers (Fermentas, USA).

Production of polyclonal antibodies

Specific antiserum against $L$. calcarifer vtg was raised in seven-month-old $(\sim 3 \mathrm{~kg})$ female New Zealand white rabbits $(n=4)$. Rabbits were initially injected with freshly purified vtg $(0.059 \mathrm{mg} / \mathrm{ml}$ protein) emulsified in Freund's Complete Adjuvant (CFA, Calbiochem) (1:1 v/v, $1 \mathrm{ml})$ and then boosted up by four additional injections of $0.02 \mathrm{mg} / \mathrm{ml}$ protein emulsified in Freund's Incomplete Adjuvant (IFA, Calbiochem) $(1: 1 \mathrm{v} / \mathrm{v}, 1 \mathrm{ml})$ at multiple subcutaneous and intradermal sites. A total of five injections were given at weeks $1,3,5,7$ and 9 . Blood $(\sim 2.0 \mathrm{ml})$ was collected at weeks 4, 6 and 10, and the serum was assayed for reactivity toward vtg by screening ELISA. When antibody titer was sufficient, blood $(\sim 10 \mathrm{ml})$ was withdrawn from the ear artery and 
allowed to clot overnight at $4{ }^{\circ} \mathrm{C}$ (Smith and Benfey 2002). Serum was separated by centrifuging the blood at $12,000 \times g$ at $4{ }^{\circ} \mathrm{C}$ for $10 \mathrm{~min}$ and then stored at $-80{ }^{\circ} \mathrm{C}$ in small aliquots. For negative antibody control, the rabbits were bled before immunization (pre-immune serum).

\section{Immunoblotting (Western blot)}

The purity of antigen and specificity of antibodies were tested by using Western blot analysis. The proteins separated by Native PAGE and SDS-PAGE were electro-blotted onto polyvinylidene fluoride, PVDF membrane (Immobilon-P, Millipore). The unstained gels were soaked in transfer buffer ( $48 \mathrm{mM}$ Tris, $39 \mathrm{mM}$ glycine, $20 \%$ methanol, $\mathrm{pH}$ 9.2) for $15 \mathrm{~min}$, and the blot was run at constant current of $300 \mathrm{~mA}$, $50 \mathrm{~V}$ for $2 \mathrm{~h}$ on ice cold using Bio-Rad Trans Blot Cell. Following the transfer, the membranes were stained with Coomassie brilliant blue R-250 (0.025 \% Coomassie Blue R-250, $40 \%$ methanol, $7 \%$ acetic acid) (Hercules, Canada). PVDF membranes were blocked by incubating in TBS (50 mM Tris, $150 \mathrm{mM} \mathrm{NaCl}, \mathrm{pH}$ 7.5) containing $3 \%$ bovine serum albumin (BSA) for $2 \mathrm{~h}$ to prevent non-specific binding sites. For immunochemical detection, the membranes were then incubated with primary antibody (anti-Vtg in rabbits) at a dilution of 1:1,500 in blocking buffer. Bound antibodies were detected by incubating with secondary antibody, HRP (Horse-Reddish Peroxidase, conjugated goat anti-rabbit IgG) (Nacalai tesque, Japan) at a dilution of 1:2,000 in blocking buffer for $2 \mathrm{~h}$ at room temperature. For visualization, membrane was incubated with substrate solution, Opti-4CN'M Substrate Kit (Bio-Rad, Hercules, CA) for $30 \mathrm{~min}$ to reveal the location of vtg. The membranes were washed with TBST [50 mM Tris, $150 \mathrm{mM} \mathrm{NaCl}, \mathrm{pH} 7.5$ containing $0.05 \%$ Tween-20 (v/v)] three times for 15 min after each incubation step. The developed membranes were photographed using gel imager.

\section{Amino acid analysis}

For analysis of amino acid composition, the purified vtg $(200 \mu \mathrm{l})$ was analyzed by high sensitivity amino acid analysis (AAA). The sample was lyophilized and resuspended in a solution of $20 \%$ acetonitrile (ACN) and $0.1 \%$ trifluoroacetic acid (TFA). Sample underwent 24-h gas-phase hydrolysis with $6 \mathrm{~N} \mathrm{HCl}$ at $110^{\circ}$
C. After hydrolysis, all amino acids were analyzed using high performance liquid chromatography (HPLC) system (Waters AccQTag Ultra) chemistry. The analyses were carried out in duplicate, and results were expressed as means. Amino Acid Standard H (Thermo Scientific Pierce) was used as calibration standard for HPLC analysis.

\section{Results}

Purification of vtg

Vitellogenin was purified from plasma of $E_{2}$-treated juvenile $L$. calcarifer by gel filtration chromatography using Sepachryl HR-300 column (GE Healthcare BioScience). Figure 1 shows the elutionlysine were present at high abundance pattern of juvenile L. calcarifer before (a) and after treatment with $17-\beta$ estradiol (b). A single symmetrical peak was obtained from purification of $E_{2}$-treated fish indicating the presence of vtg molecule. This peak was absence in chromatographic profile from non-induced. Absorbance was read at OD $280 \mathrm{~nm}$. The protein concentration of purified plasma was $0.059 \mathrm{mg} / \mathrm{ml}$ as determined by Bradford assay.

\section{Characterization of purified vtg}

Under native gradient PAGE analysis, vtg appeared as one dimeric circulating form in the $\mathrm{E}_{2}$-treated fish (Fig. 2a, lane 1) with molecular weight of $545 \mathrm{kDa}$. The same band position was also shown from plasma of natural vitellogenic females (Fig. 2a, lane 2). No protein was detected from the plasma of non-induced male (Fig. 2a, lane 3). The corresponding Western blot analysis using anti-Vtg polyclonal antibody showed strong reactivity with $\mathrm{E}_{2}$-treated $L$. calcarifer and vitellogenic females (Fig. 2b, lanes 4 and 5). There was no cross-reactivity with the plasma from the control male (Fig. 2b, lane 6). Native polyacrylamide gel electrophoresis confirmed that the purified vtg was pure and free from contaminants (Lomax et al. 1998).

Electrophoresis of the purified plasma from $\mathrm{E}_{2}$-treated L. calcarifer, vitellogenic females and untreated males under reducing conditions, is shown in Fig. 3. The molecular weight of purified vtg from 
Fig. 1 Gel filtration chromatography from plasma of juvenile L. calcarifer before (a) and after treated with 17- $\beta$ estradiol (b) using Sepachryl (16/60) HR 300 column (GE healthcare Bioscience, Uppsala, Sweden)
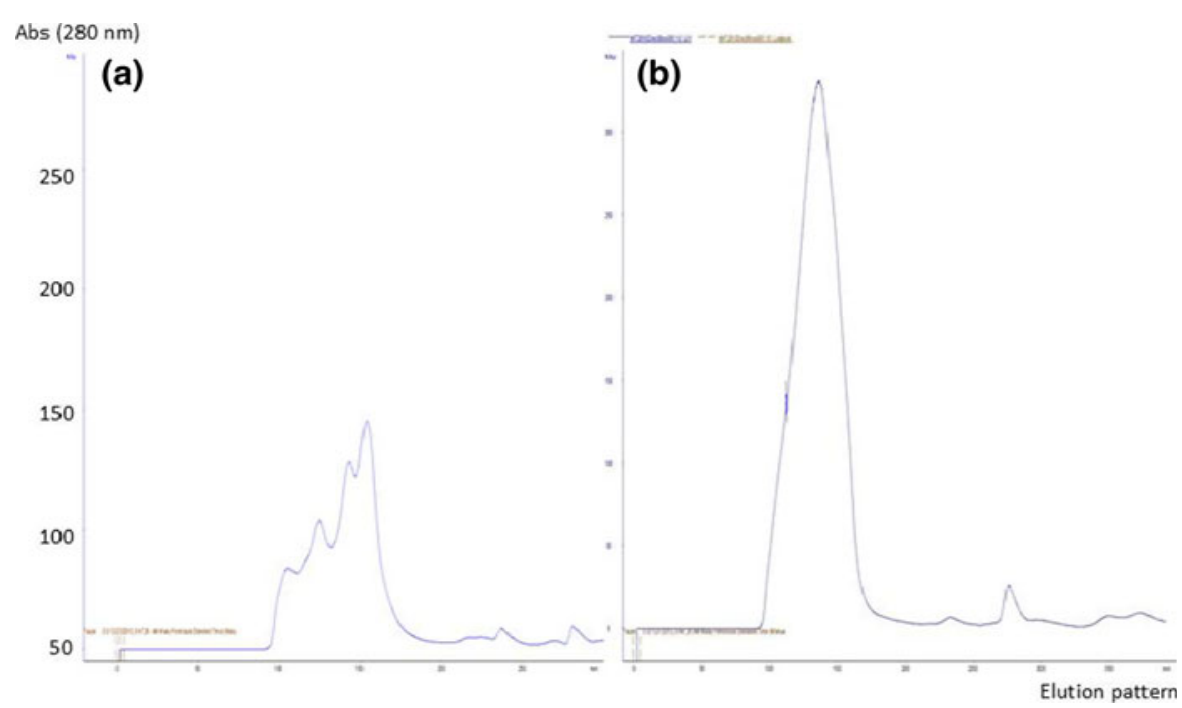

Fig. 2 a, b Native PAGE electrophoretic pattern (a) and subsequent western blot analysis (b Lanes 1 and 4 purified plasma from $17-\beta$ estradiol treated fish, lanes 2 and 5 plasma from natural vitellogenic females, lanes 3 and 6 plasma from noninduced male. The proteins were stained with

Coomassie Brilliant Blue R-250 (Bio-Rad, Hercules, Canada)

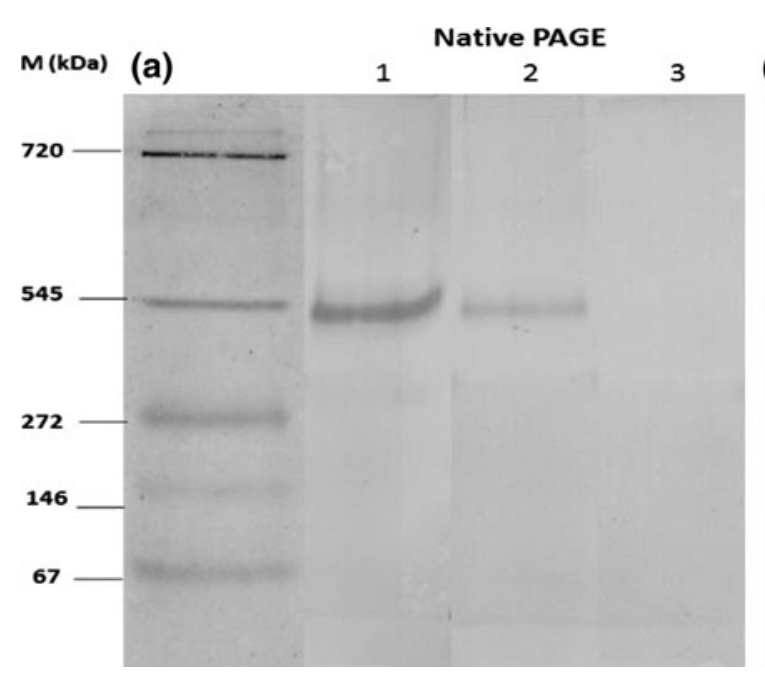

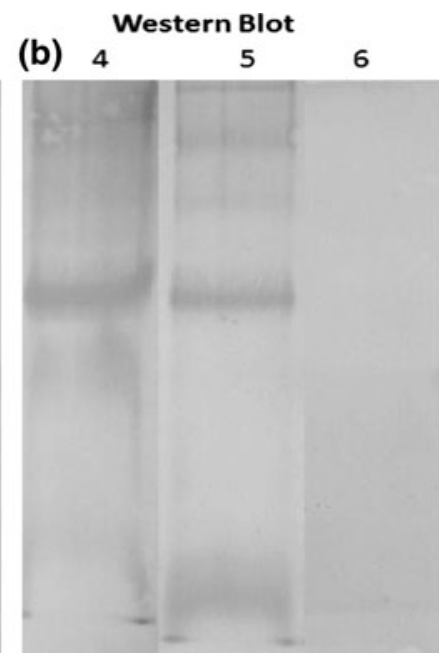

peak B resulted in five subunits with two major bands (232.86 and $118.80 \mathrm{kDa}$ ) and other minor bands (100.60, 85.80 and $39.92 \mathrm{kDa}$; lane B). The major bands were initially not appeared in the control male plasma (lane D), but shown in those induced by $17-\beta$ estradiol (lane B). The same band position occurred in vitellogenic female as in the $E_{2}$-treated fish at molecular weight of $118.80 \mathrm{kDa}$ (lane C). The corresponding Western blot analysis in SDS-PAGE showed that the specific Abvtg polyclonal antibody was immunoreacted with plasma from vitellogenic females (lane F) and only reacted with two major bands of $\mathrm{E}_{2}$-treated L. calcarifer (lane E), but did not recognize any bands in non-induced male (lane $G$ ). This indicated that vtg was specific with Abvtg, which did not react with any non-vitellogenic proteins.

On the other hand, the protein was positively stained with Sudan black B, methyl green and periodic acid/Schiffs reagent solution. This indicated the presence of lipid, phosphorus and carbohydrate in vtg molecule (Fig. 4).

Amino acid analysis

Amino acid composition of $E_{2}$-treated juvenile L. calcarifer is shown in Table 1. It contained high percentage of non-polar amino acids (glycine, alanine, proline, valine, isoleucine and leucine: $\sim 48 \%$ ). Alanine was most abundant, comprising approximately 
Fig. 3 a, b SDS-PAGE $(0.1 \%$ SDS $)(A)$ and corresponding Western blot analysis $(B)$, stained with Coomassie Brilliant Blue. Lane A molecular weight markers (Fermentas, USA); lane $B$ and $E$ purified vtg; lanes $C$ and $F$ vitellogenic females; lanes $D$ and $G$ male plasma

Fig. 4 a-c Native PAGE for determination of lipid phosphorus and carbohydrate components in vtg of L. calcarifer. Lane 1 male plasma, lane $2 \mathrm{E}_{2}$ treated plasma. Gels were stained with Sudan black B (a), methyl green (b) and Periodic acid/Schiff reagent solution (PAS) (c), respectively
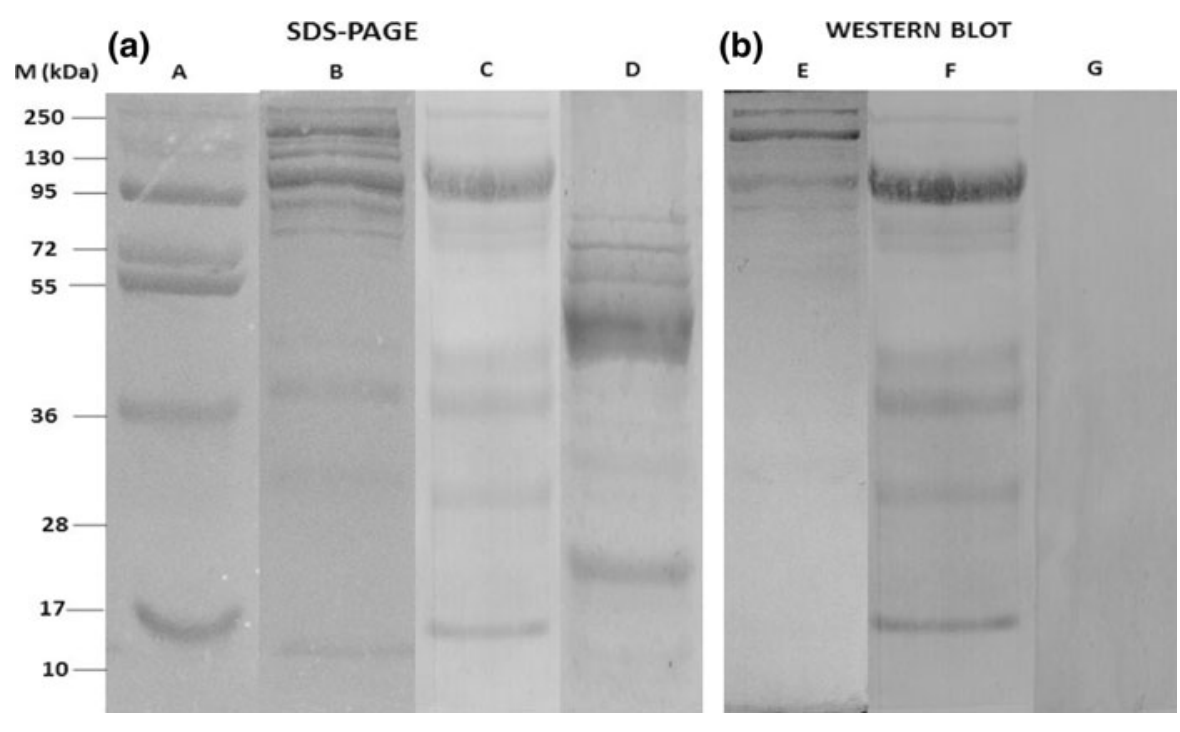

(a)

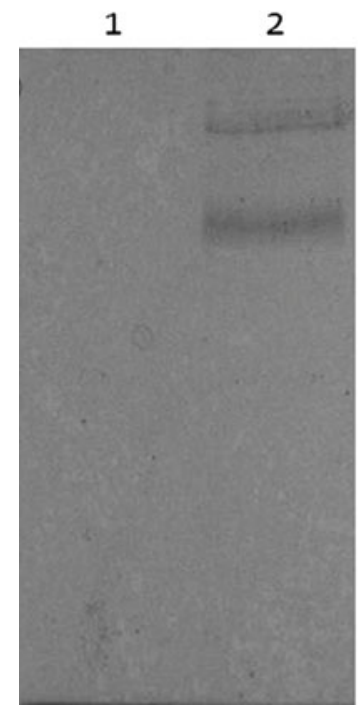

(b) 1

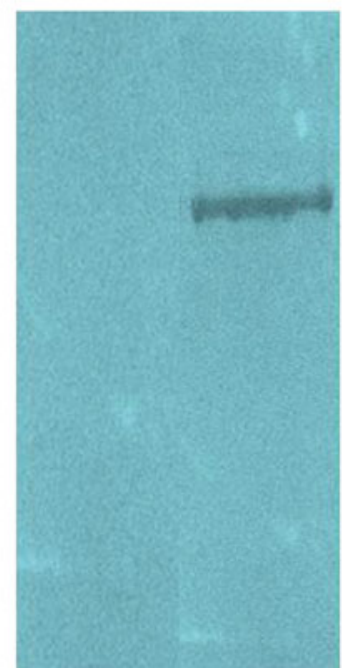

(c) 1

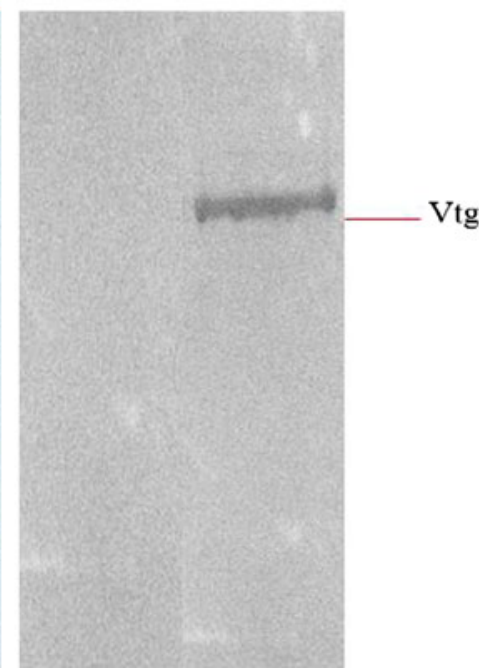

$10.1 \%$ of total amino acids. Charged and non-polar composed of approximately $52 \%$ of total amino acids. Both serine and lysine were present at high abundance 8.3 and $6.7 \%$, respectively.

\section{Discussion}

The induction of $17-\beta$ estradiol in juvenile $L$. calcarifer resulted in the production of highmolecular-weight protein $(232.18$ and $118.80 \mathrm{kDa})$. The same amount of high molecular weight protein appeared in vitellogenic female that is identified as vitellogenin (vtg). It is well established that vtg was present abundantly in blood plasma of natural vitellogenic females. However, it can be induced in males and juvenile fish by treating with estrogen hormone (Smith and Benfey 2002; Rankouhi et al. 2001).

There are a few steps involved in the isolation and separation of vtg molecules. In the present study, the vtg was isolated and purified by using gel filtration chromatography of Sepachryl HR-300 column. Chromatography was the best method to isolate vtg from blood plasma of induced fish as successfully proven by several studies (Watts et al. 2003; Roy et al. 2004; 
Table 1 Total amino acid composition of vtg in Asian sea bass in comparison with other fish species by percentage of moles

\begin{tabular}{|c|c|c|c|c|c|}
\hline \multirow[t]{2}{*}{ Amino acid } & \multicolumn{5}{|c|}{ Percentage of total amino acids } \\
\hline & $\begin{array}{l}\text { Asian sea bass } \\
\text { (the present study) }\end{array}$ & $\begin{array}{l}\text { Fathead minnow } \\
\text { (Parks et al. 1999) }\end{array}$ & $\begin{array}{l}\text { Carp (Tyler and } \\
\text { Sumpter 1990) }\end{array}$ & $\begin{array}{l}\text { Grouper (Utarabhand } \\
\text { and Bunlipatanon 1996) }\end{array}$ & $\begin{array}{l}\text { Striped bass } \\
\text { (Tao et al. 1993) }\end{array}$ \\
\hline Aspartic acid & 8.2 & 7.1 & 6.7 & 6.5 & 7.6 \\
\hline Threonine & 7.9 & 5.6 & 5.4 & 4.7 & 5.6 \\
\hline Serine & 8.3 & 6.3 & 7.6 & 5.5 & 7.2 \\
\hline Proline & 5.0 & 6.1 & 5.9 & 4.0 & 4.3 \\
\hline Glutamic acid & 11.0 & 12.3 & 11.8 & 12.0 & 11.9 \\
\hline Glycine & 7.3 & 4.6 & 5.1 & 5.5 & 4.2 \\
\hline Alanine & 10.1 & 12.0 & 12.6 & 10.2 & 12.0 \\
\hline Valine & 8.1 & 7.9 & 6.3 & 7.6 & 7.9 \\
\hline Methionine & 2.1 & 1.9 & 1.9 & 2.0 & 1.9 \\
\hline Isoleucine & 4.6 & 6.7 & 5.4 & 6.5 & 7.0 \\
\hline Leucine & 7.9 & 10.8 & 10.5 & 10.3 & 10.8 \\
\hline Tyrosine & 3.9 & 2.3 & 2.8 & 2.6 & 3.4 \\
\hline Phenylalanine & 3.9 & 2.7 & 2.8 & 2.8 & 3.4 \\
\hline Lysine & 6.7 & 6.6 & 6.3 & 7.0 & 7.3 \\
\hline Histidine & 2.1 & 2.2 & 3.4 & 2.4 & 3.1 \\
\hline Arginine & 4.1 & 4.4 & 5.0 & 7.9 & 4.9 \\
\hline Cystine/2 & ND & 0.0 & 0.1 & ND & 1.0 \\
\hline
\end{tabular}

ND Not determine

Palumbo et al. 2007; Braathen et al. 2009; Maltais and Roy 2009; Leonardi et al. 2010). A broad, single symmetrical peak (Fig. 1b) from purification of $\mathrm{E}_{2}$-treated juvenile L. calcarifer obtained in this study indicated that the peak was $\mathrm{E}_{2}$-inducible, and there was no sign of degradation occurred during the isolation process (Guzman et al. 2008). Norberg (1995) also obtained a single molecule after vtg purification in Atlantic halibut (Hippoglossus hippoglossus). Roy et al. (2004) suggested that the best condition to isolate and purify vtg was at lower temperature $\left(4^{\circ} \mathrm{C}\right)$ so as to preserve the stability of the protein. However, in this present study, purification process was carried out at room temperature. Hence, to avoid degradations, it was run in the presence of protease inhibitor (PMSF), which contributes to the isolation of single vtg molecule (Mosconi et al. 1998). Similar result was also observed for vtg in carp, Cyprinus carpio and perch, Perca fluviatilis (Hennies et al. 2003). However, purification analysis alone cannot determine that the isolated protein was vtg molecule. It needs to be confirmed by cross-reactivity of anti-vtg raised in
New Zealand white rabbits in immunoblotting analysis (Norberg 1995).

There are a few evidences proven that the purified protein was phosphoglycolipoprotein (vtg). Firstly, the plasma protein levels in induced $L$. calcarifer were increased compared to non-induced $(0.008-$ $0.059 \mathrm{mg} / \mathrm{ml}$, data not shown). This is in agreement with the finding by Mananos et al. (1994). Secondly, the specificity of antiserum confirmed by Western blot analysis showed that polyclonal antibody have strong reactivity in estrogen exposed juvenile L.calcarifer as well as vitellogenic females but failed to show any reaction with plasma from non-induced males. This indicates that the polyclonal antibody was specific, which failed to react with any nonvitellogenic proteins. Similar result was also obtained by Tao et al. (1993) in striped bass (Morone saxatilis) and Zhang et al. (2011) in Amur sturgeon (Acipenser schrenckii). Thirdly, in native gradient PAGE (samples were run without SDS and $\beta$-mercaptoethanol), the protein was positively stained for the presence of phosphorus, carbohydrate and lipid using methyl blue, periodic acid/Schiff's reagent solution (PAS) 
and Sudan black B as previously reported (Egito et al. 2001; Sun and Zhang 2001; Roy et al. 2004). Fish vtg was generally known to have high phosphorus and lipid contents that normally present as phospholipid and triglycerides (Tao et al. 1993). Fourthly, the amino acid composition of $L$. calcarifer $\mathrm{vtg}$ was very similar to vtg as previously noted from other fish species (Utarabhand and Bunlipatanon 1996; Tao et al. 1993; Parks et al. 1999; Tyler and Sumpter 1990). In the present study, high percentage of nonpolar amino acids (glycine, alanine, proline, valine, isoleucine, leucine, $48 \%$ ) was found which contributed to its lipoprotein function for transportation of endogenous lipid (Parks et al. 1999; Tao et al. 1993; Kera et al. 2000).

The analysis of vtg on native gradient PAGE resulted only one band (Fig. 2) confirmed that the isolated protein was free from contaminants. Hence, it is proved that gel filtration alone was able to completely isolated vtg in L. calcarifer. Palumbo et al. (2007) showed that the analysis of vtg by Native PAGE also resulted one circulating band interpreted that the band was dimeric form of putative vtg, which was similar to the present study. Sun and Zhang (2001) reported that the vtg from fish, amphibians and birds, nematodes and arthropods also circulate as dimeric form. Native PAGE analysis resulted an apparent molecular weight $545 \mathrm{kDa}$ of L. calcarifer $\mathrm{vtg}$, which falls within the range of vtg dimeric form as shown in other fish species: 525 and $260 \mathrm{kDa}$ in grouper (Utarabhand and Bunlipatanon 1996), $490 \mathrm{kDa}$ in carp (Fukada et al. 2003), $454 \mathrm{kDa}$ in sea bass (Mananos et al. 1994), $330 \mathrm{kDa}$ in female Bluefin tuna (Susca et al. 2001) and $390 \mathrm{kDa}$ in teleost sp. (Larsson et al. 1994).

The molecular weight of vtg (232.86 and $118.80 \mathrm{kDa}$ ) in Asian sea bass (L. calcarifer) was greater than other fish species: that is, $205 \mathrm{kDa}$ for Amur Sturgeon Acipenser schrenckii (Zhang et al. 2011), $183 \mathrm{kDa}$ for Gag Mycteroperca microlepis (Heppel and Sullivan 1999), $220 \mathrm{kDa}$ for Medaka Oryzias latipes (Shimizu et al. 2002), $150 \mathrm{kDa}$ for carp Cyprinus carpio (Fukada et al. 2003), $172 \mathrm{kDa}$ for $S$. senegalensis (Guzman et al. 2008) and $180 \mathrm{kDa}$ for sea bass D. labrax (Mananos et al. 1994). The presence of minor bands represents the monomer form of $\mathrm{vtg}$ molecule probably due to the use of sodium dodecyl sulfate (SDS) and $\beta$-mercaptoethanol, which contributes to the degradation fragments of putative vtg and similar finding was noted by Bon et al. (1997). The difference in molecular weight of vtg in each species indicated the different structure of vtg molecule.

Previous study reported that vtg was unstable and easily degraded due to the storage and handling of plasma sample (Norberg 1995; Roy et al. 2004). Hence, in this study, plasma was stored in aliquots and purified in the presence of phenylmethylsulfonyl fluoride (PMSF) in a ratio of $2: 1 \mathrm{v} / \mathrm{v}$ to prevent proteolysis of this labile protein (Watts et al. 2003).

\section{Conclusion}

In conclusion, the present study was successfully isolated and partial characterized vitellogenin in induced juvenile L. calcarifer by using gel electrophoresis, Western blotting and amino acid analysis. Further analyses of vtg levels using Abvtg proposed as indicator of maturing female stage for managing fish broodstock in captivity.

Acknowledgments We thanked En Nik Daud Nik Sin from Fisheries Research Institute (FRI), Tanjung Demong, Terengganu, Malaysia for generously supplying the fishes. A special thanks to En Ahmad Kimon Suleiman and En Ahmad Anuar Zainal from Marine Science Station, Port Dickson for technical assistance with care and sampling of the fish. A special thanks to En Mohd Kufli for his guidance for antibody production. This research was supported by Ministry of Science, Technology and Innovation (MOSTI), project no: UKM-MGI-NBD0004-2007, vote no: 5487718.

Open Access This article is distributed under the terms of the Creative Commons Attribution License which permits any use, distribution, and reproduction in any medium, provided the original author(s) and the source are credited.

\section{References}

Bon E, Barbe U, Nu ez R, Cuisset B, Pelissero C, Rodriguez J (1997) Plasma vitellogenin levels during the annual reproductive cycle of the female rainbow trout (Oncorhynchus mykiss): establishment and validation of and ELISA. Comp Biochem Physiol B 117:75-84

Boucard CV, Aceves MB, Ortega FA, Vega GA (2008) Validation of an enzyme-linked immunosorbent assay for measuring vitellogenin in California halibut (Paralichthys californicus). Environ Toxicol Chem 27(7):1614-1620

Braathen M, Mdegela RH, Correia D, Rundberget T, Myburg J, Botha C, Skaare JU, Sandvik M (2009) Vitellogenin in African catfish (Clarias garlepinus): purification, characterization, and ELISA development. J Toxicol Environ Health A 72:173-183 
Celius T, Walther BT (1998) Oogenesis in Atlantic salmon (Salmo salar L.) occurs by zonagenesis preceding vitellogenesis in vivo and in vitro. J Endocrinol 158:259-266

Department of Fisheries, Malaysia (2005) Senarai Perangkaan Tahunan. Retrieved 13th July 2011 from http://www.dof. gov.my/web/guest/224

Department of Fisheries, Malaysia (2009) Senarai Perangkaan Tahunan. Retrieved 13th July 2011 fromhttp://www.dof. gov.my/web/guest/224

Egito AS, Girardet JM, Miclo L, Gaillard JL (2001) Highly sensitive periodic acid/Schiff detection of bovine milk glycoproteins electrotransferred after nondenaturing electrophoresis, urea electrophoresis, and isoelectric focusing. INRA EDP Sci 81:775-785

Fenske M, Aerle RV, Brack S, Tyler CR, Segner H (2001) Development and validation of a homologous zebrafish (Danio rerio Hamilton-Buchanan) vitellogenin enzymelinked immunosorbent assay (ELISA) and its application for studies of estrogenic chemicals. Comp Biochem Physiol C 129:217-232

Fukada H, Fujiwara Y, Takahashi T, Hiramatsu N (2003) Carp (Cyprinus carpio) vitellogenin: purification and development of a simultaneous chemiluminescent immunoassay. Comp Biochem Physiol A 134:615-623

Guzman JM, Norberg B, Ramus J (2008) Vitellogenin, steroid plasma levels and spawning performance of cultured female Senegalese sole (Solea Senegalese). Gen Comp Endocrinol 156:285-287

Hennies M, Wiesmann M, Allner B, Sauerwein H (2003) Vitellogenin in carp (Cyprinus carpio) and perch (Perca fluviatilis): purification, characterization and development of an ELISA for the detection of estrogenic effects. Sci Total Environ 309:93-103

Heppel SA, Sullivan CV (1999) Gag (Mycteroperca microlepis) vitellogenin: purification, characterization and use for enzyme-linked immunosorbent assay (ELISA) for female maturity in three species of grouper. Fish Physiol Biochem 20:361-374

Kera Y, Kato T, Koshiba K, Yamada R (2000) Koi carp (Cyprinus carpio) vitellogenin: purification, N-terminal and internal amino acid sequences and establishment of an enzyme linked immunosorbent assay (ELISA). Jpn Environ Toxicol 3:47-62

Larsson DGJ, Hyllner SJ, Haux C (1994) Induction of vitellin envelope proteins by estradiol $17 \beta$ in 10 teleost species. Gen Comp Endocrinol 96:445-450

Leonardi M, Vera J, Terifeno E, Puchi M, Marin V (2010) Vitellogenin of the Chilean flounder (Paralichthys adpersus) as a biomarker of the south pacific. Part 1: induction, isolation and identification. Fish Physiol Biochem 36(3):757-765

Lomax DP, Roubal WT, Moore JD, Johnson LL (1998) An enzyme-linked immunosorbent assay (ELISA) for measuring vitellogenin in English sole (Pleuronectes vetulus): development, validation and cross-reactivity with other pleuronectids. Comp Biochem Physiol B 121:425-436

Luna S (2008). Lates calcarifer, barramundi: fisheries, aquaculture, gamefish, aquarium: (on-line). Fishbase

Maltais D, Roy RL (2009) Purification and partial characterization of vitellogenin from shorthead redhorse (Maxostoma macrolepidotum) and copper redhorse (Maxostoma hubbsi) and detection in plasma mucus with heterologous antibody. Fish Physiol Biochem 35(2):241-254

Mananos E, Zanuy S, Menn FL, Carillo M, Nunez J (1994) Sea bass (Dicentrarchus labrax L.) vitellogenin. I- induction, purification and partial characterization. Comp Biochem Physiol B 107:205-216

Matsubara T, Wada T, Hara A (1994) Purification and establishment of ELISA for vitellogenin of Japanese sardine (Sardinopos melanostictus). Comp Biochem Physiol B 109(4):545-555

Mendoza R, Santilla O, Revol A, Aguilera C, Cruz J (2011). Alligator gar (Atractosteus spatula, Lacepede 1803) vitellogenin: purification, characterization and establishment of an enzyme-linked immunosorbent assay. Aquacul Res 43:649-661

Mosconi G, Carnevali O, Carletta R, Nabissi M, PolzonetteMagni AM (1998) Gilthead seabream (Sparus aurata) vitellogenin: purification, partial characterization, and validation of an enzyme-linked immunosorbent assay (ELISA). Gen Comp Endocrinol 110:252-261

Nath P (1999) Some aspects of teleost vitellogenesis. In: Saksena I (ed) Ichthyology: recent research advances. Science Publishers Inc, Enfield

Norberg B (1995) Atlantic halibut (Hippoglossus hippoglossus) vitelogenin: induction, isolation and partial characterization. Fish Physiol Biochem 14:1-13

Palumbo AJ, Casenave JL, Jewel W, Doroshov SI, Tjeerdema RS (2007) Induction and partial characterization of California halibut (Paralichthys californicus) vitellogenin. Comp Biochem Physiol A 146:200-207

Parks LG, Cheek AQ, Denslow ND, Heppel SA, Mclachlan JA, LeBlanc GA, Sullivan CV (1999) Fathead minnow (Pimephales promelas) vitellogenin: purification, characterization and quantification immunoassay for the detection of estrogenic compounds. Comp Biochem Physiol C 123:113-125

Prakash O, Goswomi SV, Sehgal N (2007) Establishment of ELISA for murrel vitellogenin and chriogenin, as biomarkers of potential endocrine disruption. Comp Biochem Physiol C 146:540-551

Rankouhi TR, Holsteijn IV, Letcher R, Giesy JP, Berg MV (2001) Effects of primary exposure to environmental and natural estrogens on vitellogenin production in carp (Cyprinus carpio) hepatocytes. Toxicol Sci 67:75-80

Romano M, Rosanova P, Anteo C, Limatola E (2004) Vertebrate yolk protein: a review. Mol Reprod Dev 69:109-116

Roy RL, Yves Morin, Courtenay SC, Robichaud P (2004) Purification of vitellogenin from smooth flounder (Pleronectus putnami) and measurement in plasma by homologous ELISA. Comp Biochem Physiol B 139: 235-244

Shimizu M, Fujiwara Y, Fukada H, Hara A (2002) Purification and identification of a second form of vitellogenin from ascites of medaka (Oryzias latipes) treated with estrogen. J Exp Zool 293:726-735

Smith DS, Benfey TJ (2002) The purification and development of a quantitative enzyme linked immunosorbent assay (ELISA) for the measurement of vitellogenin in diploid and triloid brook trout (Salvelinus fontinalis). Fish Physiol Biochem 24:287-292

Sun X, Zhang S (2001) Purification and characterization of a putative vitellogenin from the ovary of amphioxus 
(Branchiostoma belcheri tsingtaunese). Comp Biochem Physiol B. 129:121-127

Susca V, Corriero A, Bridges CR, Metrio GE (2001) Study of the sexual maturity of female bluefin tuna: purification and partial characterization of vitellogenin and its use in an enzyme-linked immunosorbent assay. J Fish Biol 58:831-851

Tao Y, Hara T, Hodson RG, Woods LC, Sullivan CV (1993) Purification, characterization and immunoassay of striped bass (Morone saxatilis). Fish Physiol Biochem 12:31-46

Tyler CR, Sumpter JP (1990) The purification and partial characterization of carp, Cyprinus carpio, vitellogenin. Fish Physiol Biochem 8:111-120

Utarabhand P, Bunlipatanon P (1996) Plasma vitellogenin of grouper (Ephinephelus malabaricus): isolation, and properties. Comp Biochem Physiol C 115(2):101-110
Watts M, Pankhurst NW, Pryce A, Sun B (2003) Vitellogenin isolation, purification and antigenic cross-reactivity in three teleost species. Comp Biochem Physiol B 134: 467-476

Webster C, Lim C (2002). Nutrient requirements and feeding of finfish for aquaculture. CABI Publishing, Wallingford/ New York

Zhang Y, Qu Q, Sun D, Liu X, Suo L, Zhang Y (2011) Vitellogenin in Amur sturgeon (Acipenser schrenckii): induction, purification and changes during the reproductive cycle. J Appl Ichthyol 27:660-665 